\title{
PEMBATASAN CALON KE PALA DESA PADA PEMILIHAN KEPALA DESA ( PILKADES ) SERENTAK DALAM KONTEKS HAK ASASI MANUSIA
}

\author{
Widada \\ E-mail : widodomatonah@gmail.com \\ Mahasiswa Program Magister Ilmu Hukum, Program Pasca Sarjana \\ Fakultas Hukum Universitas Sebelas Maret Surakarta \\ Hari Purwadi \\ E-mail : H purwadie@yahoo.com \\ M. Hudi Asrori \\ E-mail : hudisayuti@gmail.com \\ Dosen Fakultas Hukum Universitas Sebelas Maret Surakarta
}

\begin{abstract}
This articles examine about Restrictions on Head Village Candidate In The Head Village Election (P ilkades) Simultaneously in the Human Rights Context. This research was doctrinal law. Form of the study is exploratory. Analysis of data using qualitative analysis approach to law and case and using primary data source, secondary and tertiary.The technique of data collection using literature and observation to strengthen analysis qualitatively. Based on research carried out produced a conclusion that reason Restrictions on Head Village Candidate In The Head Village Election (Pilkades) Simultaneously was efficiencies of budgeting process in pilkades and effectiveness of time pilkades. Two reasons was the central government took aims to effective goal using by systemic of utilities. The villages chief candidates also citizens which given protection of his political rights where political rights can only limited by constitution. So restrictions village head candidate should not be applied because it law No. 6 of 2014 about village not directly contain restriction regulation village head candidates. The restriction of the village head candidate there is only on the implementation arrangements.
\end{abstract}

Key words : Restrictions village head candidate, Human rights, Head Village Election.

\begin{abstract}
Abstrak
Artikel ini mengkaji tentang Pembatasan Calon Kepala Desa Pada Pemilihan Kepala Desa ( Pilkades ) Serentak Dalam Konteks Hak Asasi Manusia. Penelitian ini merupakan penelitian hukum doktrinal dan bentuk penelitiannya eksploratif. Pendekatan yang digunakan adalah pendekatan perundang undangan dan pendekatan kasus dengan menggunakan sumber data primer, sekunder dan tersier. Teknik Pengumpulan datanya menggunakan literatur dan observasi untuk memperkuat analisa secara kualitatif. Berdasarkan penelitian yang telah dilakukan menghasilkan suatu kesimpulan bahwa alasan pembatasan calon kepala desa pada proses pemilihan kepala desa serentak adalah efisiensi terkait dengan anggaran pelaksanaan proses pilkades tersebut dan efektifitas waktu terkait pelaksanaan pilkades. Kedua alasan tersebut diambil pemerintah pusat dengan maksud untuk mencapai tujuan yang efektif dengan menggunakan sarana - sarana yang sistemik sehingga kebijakan sentral dapat terlaksana. Calon kepala desa juga warga Negara yang diberi perlindungan terhadap hak politiknya dimana hak politik hanya dapat dibatasi dengan Undang - Undang saja. J adi pembatasan calon kepala desa hendaknya tidak diberlakukan karena Undang - Undang Nomor 6 Tahun 2016 tentang desa tidak secara langsung memuat aturan pembatasan calon kepala desa. Pembatasan calon kepala desa hanya ada pada aturan pelaksanannya.
\end{abstract}

Kata kunci : Pembatasan Calon Kepala Desa, Hak Asasi Manusia, Pemilihan Kepala Desa.

\section{A. Pendahuluan}

Negara Kesatuan Republik Indonesia terbagi atas daerah propinsi dimana daerah propinsi dibagi atas kabupaten dan kota, sedangkan kabupaten kota terbagi lagi atas desa dan kelurahan. Adanya pemberian kewenangan (otonomi) pada pemerintah kabupaten dan kota utuk mengatur semua urusan diluar urusan Pemerintah memberikan peluang yang sangat baik bagi pengembangan desa / kelurahan. 
Disamping kewenangan untuk mengembangkan desa/ kelurahan, dalam kehidupan masyarakat di desa maupun kelurahan ada kearifan lokal maupun tata nilai yang ada sejak berdirinya desa / kelurahan tersebut, dimana tata nilai atau aturan adat tersebut ada sebelum adanya aturan hukum negara muncul.

Disamping dengan adanya otonomi, Indonesia mengalami perubahan dalam bidang politik maupun dalam bidang ekonomi pada masa setelah reformasi. Komponen yang mengalami perubahan yaitu sistem kepartaian, sistem pemilihan umum dan hubungan antara pemerintah pusat dan pemerintah daerah. Pemilihan umum merupakan proses politik dimana warga negara yang telah memiliki hak memilih untuk menyalurkan suaranya untuk memilih orang - orang tertentu untuk menjadi wakil rakyat. Subyek dalam pemilu adalah pemilih dan kandidat. Sama halnya dengan warga negara lainnya, masyarakat desa juga berhak untuk memilih dan dipilih sebagai wakil rakyat. Namun saat ini politik yang terjadi di desa merupakan politik yang tidak sehat karena politik yang digunakan adalah politik uang. Politik uang dalam Pilkades menodai demokratisasi di desa khususnya dan Indonesia pada umumnya.

Desa sebagai ujung tombak pemerintahan yang paling rendah memiliki peran yang sangat strategis dalam sistem pemerintahan Negara Kesatuan Republik Indonesia, utama didalam tugas pelayanan terhadap masyarakat. Mengingat posisi Pemerintah Desa yang sangat strategis arah kebijakan pemerintah saat ini banyak yang diarahkan secara langsung ke desa baik berupa bantuan langsung ataupun program-program pembangunan lainnya. Disini juga memperkuat posisi kepala desa sebagai tokoh sentral yang ada di desa dan memiliki posisi yang bergengsi untuk diperebutkan antar warga masyarakat.

Tindak lanjut dari terbitnya Undang - Undang Nomor 6 Tahun 2014 tentang Desa adalah dengan diterbitkannya Peraturan Pemerintah Nomor 43 Tahun 2014 tentang Peraturan Pelaksanaan Undang - Undang Nomor 6 Tahun 2014 tentang Desa yang sudah dirubah dengan Peraturan Pemerintah Nomor 47 Tahun 2015 tentang Perubahan Atas Peraturan Pemerintah Nomor 43 Tahun 2014 tentang Peraturan Pelaksanaan Undang - Undang Nomor 6 Tahun 2014 tentang Desa.

Pada pasal 41 ayat ( 3 ) huruf c dari P eraturan Pemerintah Nomor 47 Tahun 2015 berbunyi : penetapan calon kepala Desa sebagaimana dimaksud pada huruf b paling sedikit 2 (dua) orang dan paling banyak 5 (lima) orang calon. Pada pelaksanaan pilkades serentak yang telah terlaksana di Kabupaten Madiun adanya klausul tersebut menimbulkan banyak yang dikeluhkan oleh warga masyarakat di desa maupun oleh para calon kepala desa.

Peraturan Pemerintah diatas jika dikaitkan dengan hak warga negara untuk memilih dan dipilih, maka termasuk hak politik warga negara dan hak tersebut juga sebagai bagian hak asasi manusia. Hak memberikan suara atau memilih ( right to vote) merupakan hak dasar ( basic right ) setiap individu atau warga negara yang harus dijamin pemenuhannya oleh negara dan pengaturan ini terdapat dalam UUD 1945. Ketentuan UUD 1945 mengarahkan bahwa negara harus memenuhi segala bentuk hak asasi setiap warga negaranya, khususnya berkaitan dengan hak pilih setiap warga negara dalam pemilihan umum, pemilihan presiden, dan pemilihan kepala daerah.

Berkaitan dengan hak memilih dan dipilih diatas jika dikaitkan dengan pemilihan kepala desa maka ketentuan yang ada pada pasal 41 ayat ( 3 ) huruf c pada Peraturan Pemerintah Nomor 47 Tahun 2015 seharusnya penetapannya tidak dibatasi hanya pada maksimal 5 ( lima ) calon saja dikarenakan banyak warga masyarakat desa yang dikehendaki warga untuk mejadi calon kepala desa dengan menunjukkan kemampuannya dengan mengikuti kegiatan pemilihan kepala desa serentak yang dilakukan di tingkat pemerintah kabupaten di seluruh Indonesia .

Dari uraian diatas maka artikel ini hendak mengkaji mengenai Pembatasan Calon Kepala Desa Pada Pemilihan Kepala Desa ( Pilkades ) Serentak Dalam Konteks Hak Asasi Manusia. Dengan tinjauan pertama, terkait alasan dikeluarkannya kebijakan pembatasan calon kepala desa pada pemilihan kepala desa ( pilkades ) serentak oleh pemerintah. Kedua, tinjauan pembatasan calon kepala desa pada pilkades serentak dalam konteks hak asasi manusia.

\section{B. Metode Penelitian}

Apabila dilihat dari bentuknya, penelitian ini termasuk ke dalam bentuk penelitian eksploratif. Penelitian eksploratif dilakukan apabila pengetahuan tentang suatu gejala yang akan diselidiki masih kurang sekali atau bahkan tidak ada ( Setiono, Surakarta, $2005: 6$ ).

Ditinjau dari spesifikasi penelitian, maka artikel ini merupakan penelitian hukum doktrinal. Dalam 
hal ini, penelitian menyediakan ekspos sistematis terhadap peraturan yang mengatur kategori hukum tertentu, menganalisis hubungan antar peraturan, menjelaskan area yang mengalami hambatan, dan bahkan memperkirakan perkembangan mendatang.

\section{Hasil Penelitian dan Pembahasan}

1. Pembatasan Calon Kepala Desa pada Pemilihan Kepala Desa (Pilkades) Serentak.

Dari hasil penelitian yang dilakukan penulis dari berbagai literatur dan dilokasi penelitian dapat diketahui bahwa maksud ataupun tujuan pembatasan calon kepala desa dalam pilkades serentak menurut Undang - Undang Nomor 6 Tahun 2014 tentang Desa belum dapat diketahui dengan pasti. Akan tetapi jika melihat dari sudut pandang waktu dan biaya yang diperlukan dalam melaksanakan pemilihan kepala desa serentak sekarang ini, pada dasarnya pertimbangan pembatasan dapat dilaksanakan. Alasan pembatasan calon kepala desa dalam pemilihan kepala desa serentak memiliki beberapa sudut pandang yang salah satunya meliputi :

\section{a. Efektifitas.}

Terbitnya Undang-undang Nomor 6 Tahun 2014 tentang Desa terjadi perubahan yang mendasar pada posisi pemerintahan desa. Tentunya untuk melaksanakan ketentuan ini secara penuh pasti perlu waktu untuk mengkaji dari berbagai sudut pandang yang ada.

Efektifitas menjadi pertimbangan yang mendasar untuk merumuskan solusi yang tepat bagi Pemerintah Kabupaten Madiun khususnya dan pemerintah pusat pada umumnya dalam melaksanakan pemilihan kepala desa secara serentak. J angan sampai terjadi adanya keresahan masyarakat yang nantinya menjadi konstituen langsung terkait pemilihan calon kepala desa. Apabila muncul keresahan yang ada di masyarakat maka akan berdampak langsung terhadap pelaksanaan kegiatan pemilihan kepala desa di suatu desa.

Pembatasan calon kepala desa pada pemilihan kepala desa yang juga wujud dari kewenangan melekat yang dimiliki desa secara serentak, dilakukan untuk mempercepat proses terpilinnya kepala desa di suatu desa yang mana harapan dari pembatasan calon yang ada waktu untuk pelaksanaan pilkades tidak mengalami kemoloran sehingga penetapan kepala desa terpilih nantinya bisa tepat waktu sesuai jadwal yang ditentukan oleh pemerintah pusat, pemerintah daerah maupun pemerintah desa. Dikhawatirkan jika pelaksanaan pemilihan kepala desa mengalami sengketa dan sengketa tersebut dialami lebih dari satu desa di seluruh Indonesia maka tidaklah heran jika waktu yang dibutuhkan setiap pemerintah desa untuk mendapatkan kepala desa terpilih menjadi berkepanjangan.

\section{b. Efisiensi}

Efisiensi biaya penyelenggaraan menjadi alasan lain yang sangat logis untuk dikemukakan oleh pemerintah pusat dalam kaitannya dengan pembatasan calon kepala desa pada pemilihan kepala desa serentak yang dilakukan di seluruh Indonesia. Dengan asumsi ini pemerintah dapat menghitung secara kasar mengenai berapa banyaknya anggaran yang dikeluarkan dalam menyelenggarakan pemilihan kepala desa serentak jika calon kepala desanya lebih dari 5 ( lima ) orang. Pembengkakan anggaran ini tentunya harus direspon pemerintah pusat dalam mengeluarkan aturan mengenai pemilihan kepala desa.

Alasan pembatasan calon kepala desa dalam pemilihan kepala desa serentak di dalam peraturan perundang - undangan tentang Desa yaitu Undang - Undang Nomor 6 Tahun 2014 tentang Desa belum diketahui secara jelas, akan tetapi dalam aturan pelaksanaan dari Undang - Undang Nomor 6 Tahun 2014 tentang Desa telah dicantumkan aturan mengenai pembatasan calon kepala desa pada pemilihan kepala desa serentak.

Menurut penulis alasan mengenai pembatasan calon kepala desa yang tertuang dalam aturan atau perundang - undangan termasuk ke dalam rasionalitas formal. Dimana tindakan pemerintah pusat, dalam hal ini selaku pembuat aturan mengenai desa diarahkan pada tujuan yang ditentukan oleh harapan pemerintah pusat terhadap perilaku objek dalam lingkungan pemerintahan yaitu masing - masing pemerintah daerah dan 
perilaku manusia lain yaitu masyarakat yang ada di setiap desa yang ada di seluruh Indonesia. Kepentingan pemerintah pusat menjadi sentral dan sarana-sarana yang digunakan untuk mencapai tujuan dipertimbangkan secara sistematis dan tindakan yang diambil oleh pemerintah pusat untuk melaksanakan aturan mengenai desa dilakukan seefisien mungkin dengan cara yang terbaik.

Di sisi lain penerapan aturan mengenai desa juga didesak dengan adanya berbagai kepentingan politik. Dimana pada saat kehidupan demokrasi kenegaraan mengalami perubahan, desakan dari pihak - pihak yang berkepentingan terkaitkelangsungan jalannya kekuasaan melalui jalur desa semakin marak berlangsung kepada pemerintah pusat, sehingga secara cepat pemerintah pusat merespon perubahan tersebut dengan mengeluarkan aturan mengenai desa dengan terbitnya Undang - Undang Nomor 6 Tahun 2014 tentang Desa.

Alasan pembatasan calon kepala desa pada pemilihan kepala desa serentak yang dilakukan oleh pemerintah pada akhirnya adalah untuk merespon dari dorongan untuk segera menetapkan aturan khusus mengenai desa yang datang dari berbagai elemen masyarakat termasuk elemen masyarakat yang berkecimpung di dunia politik maupun kelompok masyarakat penekan ( pressure group ) dengan mengeluarkan alasan terkait efektifitas dan efisiensi pelaksanaan proses pemilihan kepala desa serentak.

2. Pembatasan Calon Kepala Desa pada Pemilihan Kepala Desa ( Pilkades ) Serentak dalam konteks Hak Asasi Manusia.

Pengakuan HAM oleh masyarakat dunia ditandai dengan munculnya Universal Declaration of Human Rights ( Deklarasi Universal Tentang Hak Asasi Manusia ) oleh Persatuan Bangsa-Bangsa (PBB) pada tanggal 10 Desember 1948. Berdasarkan pasal 1 Deklarasi Universal Tentang Hak Asasi Manusia disebutkan perlu adanya pengakuan, penghargaan sekaligus jaminan internasional bahwa setiap orang dilahirkan merdeka dan mempunyai martabat dan hakhak yang sama. Mereka di karuniai akal dan budi dan kehendaknya bergaul satu sama lain dalam persaudaraan. Dengan adanya deklarasi tersebut mengartikan bahwa telah ada komitmen moral dunia internasional pada
HAM sehingga setiap negara harus memberi jaminan HAM dalam konstitusi atau undang undang dasamya sebagai bentuk pemenuhan kewajiban internasional.

Di Indonesia pada pembukaan Undang - Undang Dasar Republik Indonesia Tahun 1945 telah mengakui perlindungan terhadap Hak Asasi Manusia, setelah berkembangnya paradigma dan budaya kebangsaan pada bangsa Indonesia selanjutnya terbitlah Undang - Undang Nomor 39 Tahun 1999 tentang Hak Asasi Manusia, khususnya pada Pasal 23 ayat ( 1 ) menyatakan bahwa: "setiap orang bebas untuk memilih dan mempunyai keyakinan politiknya ". S elanjutnya di ketentuan Pasal 43 ayat ( 1 ) Undang - Undang ini menyatakan bahwa: “ setiap warga Negara berak untuk dipilih dan memilih dalam pemilihan umum berdasarkan persamaan hak melalui pemungutan suara yang langsung, umum, bebas, rahasia, jujur dan adil sesuai dengan ketentuan peraturan perundang - undangan ".

Hak memberikan suara atau memilih (right to vote) merupakan hak dasar (basic right) setiap individu atau warga negara yang harus dijamin pemenuhannya oleh Negara. Ketentuan mengenai ini, diatur dalam Pasal 1 ayat (2), Pasal 2 ayat (1), P asal 6A (1), Pasal 19 ayat (1) dan Pasal 22C ayat (1) UUD 1945. Perumusan sejumlah pasal ters ebut sangat jelas bahwa tidak dibenarkan adanya diskirminasi mengenai ras, kekayaan, agama dan keturunan. Ketentuan UUD 1945 di atas mengarahkan bahwa negara harus memenuhi segala bentuk hak asasi setiap warga negaranya, khususnya berkaitan dengan hak pilih setiap warga negara dalam P emilihan Umum (Pemilu), Pemilihan Presiden (Pilpres) dan Pemilihan Kepala Daerah (Pilkada) di Indonesia. Makna dari ketentuan tersebut menegaskan bahwa segala bentuk produk hukum perundangundangan yang mengatur tentang Pemilu, Pilpres dan Pilkada, khususnya mengatur tentang hak pilih warga negara, seharusnya membuka ruang yang seluas-luasnya bagi setiap warga negara untuk bisa menggunakan hak pilinnya, sebab pembatasan hak pilih warga negara merupakan salah satu bentuk pelanggaran HAM.

Sementara hak dipilih secara tersurat diatur dalam UUD 1945 mulai Pasal 27 ayat (1) dan (2); Pasal 28, Pasal 28D ayat 
(3), Pasal 28E ayat (3). Pengaturan ini menegaskan bahwa negara harus memenuhi hak asasi setiap warga negaranya, khususnya dalam keterlibatan pemerintahan untuk dipilih dalam event pesta demokrasi yang meliputi Pemilihan Umum ( Pemilu), Pemilihan Presiden ( Pilpres) dan Pemilihan Kepala Daerah ( Pilkada ).

International CovenantOnCivil And Political Rights ( ICCPR 1966 ) berkaitan dengan hak politik warga negara menegaskan dalam Pasal 25 bahwa:

"Setiap warga negara harus mempunyai hak dan kesempatan yang sama untuk tanpa pembedaan apapun dan tanpa pembatasan yang tidak wajar untuk berpartisipasi dalam menjalankan segala urusan umum baik secara langsung maupun melalui wakil-wakil yang dipilih secara bebas, selanjutnya untuk memilih dan dipilih pada pemilihan berkala yang bebas dan dengan hak pilih yang sama dan universal serta diadakan melalui pengeluaran suara tertulis dan rahasia yang menjamin para pemilih untuk menyatakan kehendak mereka dengan bebas, dan untuk mendapatkan pelayanan umum di negaranya sendiri pada umumnya atas dasar persamaan ".

Ketentuan di atas ditujukan untuk menegaskan bahwa hak politik, memilih dan dipilih merupakan hak asasi yang dimiliki oleh setiap manusia. Pembatasan, penyimpangan, peniadaan dan penghapusan hak tersebut merupakan bentuk pelanggaran hak asasi manusia yang dimiliki oleh setiap warga negara.

Menurut ketentuan Pasal 23 ayat (1) Undang - Undang Nomor 39 Tahun 1999 tentang Hak Asasi Manusia dinyatakan bahwa: "Setiap orang bebas untuk memilih dan mempunyai keyakinan politiknya". Lebih lanjut menurut ketentuan Pasal 43 ayat (1) Undang - Undang ini, dinyatakan bahwa: “ Setiap warga negara berhak untuk dipilih dan memilih dalam pemilihan umum berdasarkan persamaan hak melalui pemungutan suara yang langsung, umum, bebas, rahasia, jujur dan adil sesuai dengan ketentuan peraturan perundang - undangan". Kedua ketentuan pasal di atas jelas menunjukkan adanya jaminan yuridis yang melekat bagi setiap warga Negara Indonesia itu sendiri untuk melaksanakan hak memilih dan dipilihnya.
Terkait dengan pembatasan calon kepala desa pada proses pemilihan kepala desa serentak, maka penulis akan menganalisa dengan menggunakan aturan mengenai pembatasan hak asasi manusia.

Pelaksanaan hak asasi manusia bukanlah sesuatu yang bersifat absolut dan mutlak, sangat dimungkinkan adanya ruang pembatasan untuk menjamin hak dan kebebasan orang lain serta memenuhi tuntutan yang adil sesuai dengan pertimbangan moral, nilai-nilai agama, keamanan, dan ketertiban umum dalam suatu masyarakat demokratis. $\mathrm{Hal}$ ini ditegaskan dalam ketentuan Pasal 28 J ayat (2) UUD 1945, dinyatakan bahwa :

“Dalam menjalankan hak dan kebebasannya, setiap orang wajib tunduk kepada pembatasan yang ditetapkan dengan Undang - Undang ( UU ) dengan maksud semata-mata untuk menjamin pengakuan serta penghormatan atas hak dan kebebasan orang lain dan untuk memenuhi tuntutan yang adil sesuai dengan pertimbangan moral, nilai-nilai agama, keamanan, dan ketertiban umum dalam suatu masyarakat demokratis ".

Berdasarkan ketentuan Pasal $28 \mathrm{~J}$ ayat (2) di atas, jelas menunjukkan bahwa dalam menjalankan hak dan kebebasannya, dimungkinkan adanya pembatasan. Pembatasan sebagaimana dimaksud pada ketentuan pasal tersebut harus diatur dalam Undang - Undang, artinya tanpa adanya pengaturan tentang pembatasan tersebut maka tidak dimungkinkan dilakukannya pembatasan terhadap pelaksanaan hak dan kebebasan yang melekat pada setiap orang dan warga negara Indonesia.

Kerangka hukum ini perlu untuk dipahami secara bersama dalam rangka memaknai " hak " yang telah diakui dan diatur secara hukum di Indonesia. A pabila mengacu pada ketentuan yang diatur dalam Undang Undang Nomor 39 Tahun 1999 tentang Hak Asasi Manusia, sepintas menunjukkan adanya bentuk pelanggaran hukum terhadap jaminan hak politik yang melekat pada warga negara Indonesia. Adanya ruang untuk melakukan pembatasan terhadap hak yang melekat pada setiap orang dan warga negara Indonesia, melahirkan pengaturan bahwa hak politik tersebut dimungkinkan untuk tidak melekat pada semua warga negara Indonesia. Artinya, hak politik tersebut diberikan pembatasan- 
pembatasan sehingga warga Negara yang diberikan jaminan untuk memiliki hak politik tersebut benar-benar merupakan warga negara yang telah memenuhi persyaratan yang telah ditentukan.

Dari uraian diatas maka yang menyebutkan pembatasan calon kepala desa ada pada aturan pelaksanaan daripada Undang - Undang Nomor 6 Tahun 2014 tentang Desa. Pada Undang - Undang Nomor 6 Tahun 2014 tentang Desa sendiri secara tersurat tidak menyebutkan pembatasan calon kepala desa pada pelaksanaan pemilihan kepala desa yang dilakukan secara serentak.

J ika dikaitkan dengan hak politik warga Negara. Proses pemilihan kepala desa ( pilkades ) pada tahap pencalonan kepala desa maka setiap warga desa yang ada di setiap desa di Indonesia memiliki hak yang sama untuk dapat menjadi calon kepala desa dengan menyesuaikan sesuai kriteria atau persyaratan yang ada pada aturan mengenai pemilihan kepala desa.

Merujuk ketentuan Pasal 28 J ayat (2) UUD 1945, maka Undang - Undang Nomor 6 Tahun 2014 tentang Desa tidak memuat secara jelas aturan mengenai pembatasan mengenai calon kepala desa pada pemilihan kepala desa ( pilkades) secara serentak. Aturan mengenai pembatasan hanya tersurat pada aturan pelaksanaannya yaitu Peraturan Menteri Dalam Negeri Republik Indonesia Nomor 112 Tahun 2014 tentang Pemilihan Kepala Desa.

J adi setiap warga desa yang memenuhi syaratatau kriteria sesuai peraturan perundang - undangan yang berlaku dalam pencalonan kepala desa calon seharusnya diperkenankan ikut dalam proses pemilihan kepala desa serentak pada tahapan pencalonan kepala desa tanpa pembatasan jumlah calon kepala desa.

\section{Simpulan}

1. Pemerintah memberikan pembatasan terkait jumlah calon kepala desa pada pemilihan kepala desa ( pilkades) serentak dengan alasan yang dikaji berdasarkan teori rasional formal sebagai berikut:

\section{a. Efektifitas.}

Efektifitas menjadi pertimbangan yang mendasar untuk merumuskan solusi yang tepat bagi Pemerintah Kabupaten Madiun khususnya dan pemerintah pusat pada umumnya dalam melaksanakan pemilihan kepala desa secara serentak.

Efektifitas diatas menjadi alasan pembatasan calon kepala desa pada pemilihan kepala desa yang juga merupakan wujud dari kewenangan melekat yang dimiliki desa secara serentak dilakukan guna mempercepat proses terpilinnya kepala desa di suatu desa yang mana harapan dari pembatasan calon yang ada waktu untuk pelaksanaan pilkades tidak mengalami kemoloran sehingga penetapan kepala desa terpilih nantinya bisa tepat waktu sesuai jadwal yang ditentukan oleh pemerintah pusat, pemerintah daerah maupun pemerintah desa.

\section{b. Efisiensi}

Efisiensi biaya penyelenggaraan menjadi alasan lain yang sangat logis untuk dikemukakan oleh pemerintah pusat dalam kaitannya dengan pembatasan calon kepala desa pada pemilihan kepala desa serentak yang dilakukan di seluruh Indonesia. Dengan asumsi ini pemerintah dapat menghitung secara kasar mengenai berapa banyaknya anggaran yang dikeluarkan dalam menyelenggarakan pemilihan kepala desa serentak jika calon kepala desanya lebih dari 5 ( lima ) orang. Pembengkakan anggaran ini tentunya harus direspon pemerintah pusat dalam mengeluarkan aturan mengenai pemilihan kepala desa.

2. Pembatasan calon kepala desa pada pemilihan kepala desa ( pilkades ) serentak ditinjau dalam konteks hak asasi manusia, dapat penulis simpulkan sebagai berikut:

Pelaksanaan hak asasi manusia bukanlah sesuatu yang bersifat absolut dan mutlak, sangat dimungkinkan adanya ruang pembatasan untuk menjamin hak dan kebebasan orang lain serta memenuhi tuntutan yang adil sesuai dengan pertimbangan moral, nilai-nilai agama, keamanan, dan ketertiban umum dalam suatu masyarakat demokratis. Hal ini ditegaskan dalam ketentuan Pasal 28 J ayat (2) UUD 1945, dinyatakan bahwa :

"Dalam menjalankan hak dan kebebasannya, setiap orang wajib tunduk kepada pembatasan yang ditetapkan 
dengan Undang - Undang ( UU ) dengan maksud semata-mata untuk menjamin pengakuan serta penghormatan atas hak dan kebebasan orang lain dan untuk memenuhi tuntutan yang adil sesuai dengan pertimbangan moral, nilai-nilai agama, keamanan, dan ketertiban umum dalam suatu masyarakat demokratis ".

Dari uraian diatas maka yang menyebutkan pembatasan calon kepala desa ada pada aturan pelaksanaan daripada Undang - Undang Nomor 6 Tahun 2014 tentang Desa. Pada Undang - Undang Nomor 6 Tahun 2014 tentang Desa sendiri secara tersurat tidak menyebutkan pembatasan calon kepala desa pada pelaksanaan pemilihan kepala desa yang dilakukan secara serentak.

J adi dalam proses pemilihan kepala desa ( pilkades ) pada tahap pencalonan kepala desa maka setiap warga desa yang ada di setiap desa di Indonesia memiliki hak yang sama untuk dapat menjadi calon kepala desa dengan menyesuaikan sesuai kriteria atau persyaratan yang ada pada aturan mengenai pemilihan kepala desa.

\section{E. Saran}

a. Pemerintah Pusat melalui Kementerian Dalam Negeri dalam menerbitkan kebijakan / aturan perundang - undangan hendaknya memberikan kesempatan / ruang kepada Pemerintah Daerah untuk memberikan saran masukan kebijakan yang akan diterbitkan lewat Forum diskusi atau Rapat Koordinasi, sehingga setelah kebijakan ditetapkan sudah ada langkah-langkah antisipasi. Selain itu untuk kebijakan yang mengalami perubahan yang sangat mendasar guna tertib pelaksanaannya diharapkan ketentuan - ketentuan pelaksanaan yang diturunkan kepada Pemerintah Daerah diberi batasan waktu akhir pelaksanaan peraturan, jangan aturan turun langsung harus dilaksanakan ;

b. Perubahan aturan pelaksanaan dari Undang - Undang Nomor 6 Tahun 2014 tentang Desa, hendaknya dikoordinasikan dan dilakukan uji kelayakan di tingkat pemerintah daerah guna tercapainya pelaksanaan kebijakan publik yang baik sehingga pemerintah daerah selaku pelaksana tidak mengalami kebingungan dalam menerapkan setiap aturan yang diterbitkan pemerintah pusat.

\section{Daftar Pustaka}

Bambang Sunggono. 1997. Metodologi Penelitian Hukum . Jakarta : Raja Grafindo Persada.

Bagir Manan. 2001. Menyonsong Fajar Otonomi Daerah. Yogyakarta : Pusat Studi Hukum Universitas Islam Indonesia.

Burhan Ashshofa. 2001. Metodologi Penelitian Hukum. J akarta : Rineka Cipta.

Dede Rosyada,dkk. 2003. Pendidikan Kewarganegaraan ( Civic Education ) : Demokrasi, Hak Asasi Manusia dan Masyarakat Madani. J akarta : Prenada Media.

Edward III dalam J oko Widodo. 2007. Analilsis Kebijkan Publik, Konsep dan Aplikasi Analisis Proses Kebijakan Publik. Malang : Bayu Media Publishing

Friedman dalam Setiono. 2004. Pemahaman Terhadap Metodologi Penelitian Hukum. Surakarta.

Harold D. Laswell dan Abraham Kaplan dan Carl J. Freidrich dikutip J oko Purwono. 1989. Analisis Kebijaksanaan : Dari Formulasi Ke Implementasi Kebijaksanaan Negar. J akarta : Bumi Aksara.

HB. Sutopo. 2002. Metodologi Penelitian Kualitatif. Surakarta : UNS Press.

J oko Widodo. 2001. Good Governance Telaah dari Dimensi: Akuntabilitas dan Kontrol Birokrasi Pada Era Desentralisasi dan Otonomi Daerah, Surabaya : Insan Cendekia.

J oko Purwanto. 1989. Analisis Kebijaksanaan : Dari Formulasi ke Implementasi Kebijaksanaan Negara. 
J akarta : Bumi Aksara.

Kartasamista, Ginandjar. 1997. Membangun Sumber Daya Sosial Profesional. J akarta : Bappenas.

Koentjaraningrat. 1994. Kebudayaan, Mentalitas dan Pembangunan. J akarta : PT Gramedia.

Moleong. 2000. Metodologi Penelitian Kualitatif. Bandung : PT. Alumni,

Nystrom and Sturbuck. 1981. Hand Book of Organization Design, Oxford : Oxford University Press.

Prawirosentono, Suyudi. 1999. Kebijakan Kinerja Karyawan : Kiat Membangun Organisasi Kompetitif Menjelang Perdagangan Bebas Dunia. Yogyakarta : BPFE.

Satjipto Raharjo. 1986. Hukum dan Masyarakat. Bandung : Angkasa.

Soerjono Soekanto. 1982. Kesadaran Hukum dan Kepatuhan Hukum. J akarta : Rajawali.

Thomas R. Dye dalam Esmi Warasih. 2005. Pranata Hukum Sebuah Telaah Sosiologis. Semarang : PT. Suryandaru Utama.

Wiliam Dunn dan Muhadjir Darwin. 1995. Pengantar Analis is Kebijakan Publik. Yogyakarta : Gajah Mada University P ress.

William dan Elmore dalam J.A.M Maarse dikutif Bambang Sunggono. 1994. Hukum dan Kebijakan Publik. Jakarta Sinar : Grafika.

\section{J URNAL NASIONAL}

Hidayat,2013. "Pengakuan Hukum Terhadap Hak Ulayat Masyarakat Hukum Adat Dan Hambatan Implementasinya ". J urnal HAM. No. 2 Volume 4. J akarta : Badan Penelitian dan Pengembangan HAM Kementerian Hukum dan Hak Asasi Manusia R.I.

Siti Koomariah,2010. "Partisipasi Publik ( Public Participation ) Dalam Konsep Pembangunan Untuk Semua ( Development for All ) “. J urnal Sekretariat Negara R.I. No. 16. J akarta : Sekretariat Negara R.I.

\section{PERUNDANG - UNDANGAN}

Undang - Undang Nomor 39 Tahun 1999 tentang Hak Asasi Manusia ;

Undang - Undang Nomor 23 Tahun 2014 tentang Pemerintahan Daerah ;

Undang - Undang Nomor 6 Tahun 2014 tentang Desa ;

Peraturan Pemerintah Nomor 43 Tahun 2014 tentang Peraturan Pelaksanaan Undang - Undang Nomor 6 Tahun 2014 tentang Desa ;

Peraturan Pemerintah Nomor 47 Tahun 2015 tentang Perubahan Atas Peraturan Pemerintah Nomor 43 Tahun 2014 tentang Peraturan Pelaksanaan Undang - Undang Nomor 6 Tahun 2014 tentang Desa. 